\title{
Metoprolol and Its Degradation and Transformation Products Using AOPs-Assessment of Aquatic Ecotoxicity Using QSAR
}

\author{
Melanie Voigt ${ }^{1}\left(\right.$, Indra Bartels ${ }^{1,2}$, Dorothee Schmiemann ${ }^{1,2}$, Lars Votel $^{1}$, Kerstin Hoffmann-Jacobsen ${ }^{1}$ \\ and Martin Jaeger $1, * \mathbb{D}$ \\ 1 Department of Chemistry and ILOC, Niederrhein University of Applied Sciences, Adlerstraße 32, \\ D-47798 Krefeld, Germany; Melanie.voigt@hs-niederrhein.de (M.V.); indra.bartels@stud.uni-due.de (I.B.); \\ Dorothee.schmiemann@hs-niederrhein.de (D.S.); lars.votel@hotmail.de (L.V.); \\ kerstin.hoffmann-jacobsen@hs-niederrhein.de (K.H.-J.) \\ 2 Faculty of Chemistry, University Duisburg-Essen, Universitätsstraße 2, D-45141 Essen, Germany \\ * Correspondence: martin.jaeger@hs-niederrhein.de; Tel.: +49-(0)2151-822-4188
}

check for updates

Citation: Voigt, M.; Bartels, I.; Schmiemann, D.; Votel, L.; Hoffmann-Jacobsen, K.; Jaeger, M. Metoprolol and Its Degradation and Transformation Products Using AOPs-Assessment of Aquatic Ecotoxicity Using QSAR. Molecules 2021, 26, 3102. https://doi.org/ 10.3390/molecules26113102

Academic Editor: Marcello Brigante

Received: 28 April 2021

Accepted: 19 May 2021

Published: 22 May 2021

Publisher's Note: MDPI stays neutral with regard to jurisdictional claims in published maps and institutional affiliations.

Copyright: (C) 2021 by the authors. Licensee MDPI, Basel, Switzerland. This article is an open access article distributed under the terms and conditions of the Creative Commons Attribution (CC BY) license (https:// creativecommons.org/licenses/by/ $4.0 /)$.

\begin{abstract}
Pharmaceuticals are found in waterbodies worldwide. Conventional sewage treatment plants are often not able to eliminate these micropollutants. Hence, Advanced Oxidation Processes (AOPs) have been heavily investigated. Here, metoprolol is exposed to UV irradiation, hydrogen peroxide, and ozonation. Degradation was analyzed using chemical kinetics both for initial and secondary products. Photo-induced irradiation enhanced by hydrogen peroxide addition accelerated degradation more than ozonation, leading to complete elimination. Degradation and transformation products were identified by high-performance liquid-chromatography coupled to high-resolution higher-order mass spectrometry. The proposed structures allowed to apply Quantitative StructureActivity Relationship (QSAR) analysis to predict ecotoxicity. Degradation products were generally associated with a lower ecotoxicological hazard to the aquatic environment according to OECD QSAR toolbox and VEGA. Comparison of potential structural isomers suggested forecasts may become more reliable with larger databases in the future.
\end{abstract}

Keywords: ecotoxicity; AOPs; HPLC-HRMS; Metoprolol; QSAR

\section{Introduction}

Metoprolol, a beta-blocker and one of the most commonly prescribed blood pressure medicines, is introduced into the water cycle through incomplete elimination in sewage treatment plants and is therefore most frequently detected in surface waters worldwide [1,2]. Deleterious effects on fish, invertebrates, and green algae were reported $[3,4]$. The European Union Directive 93/67EEC classified metoprolol as harmful $\left(10<\mathrm{EC}_{50}<\right.$ $100 \mathrm{mg} \mathrm{L}^{-1}$ ) to aquatic organisms. The database "Pharmaceuticals in the Environment" of the German Federal Environment Agency records over 1750 entries about the presence in different water bodies of metoprolol worldwide in the year 2018. In Asia, the highest metoprolol concentrations in surface water were detected, amounting to several micrograms per liter $[1,2,5]$. Similar concentrations were also found in wastewater treatment plant (WWTP) effluents in Western Europe. Maszkowska et al. reported on metoprolol's stability to hydrolysis, bioavailability, and mobility in the environment [6]. In their studies, they found minor hazardous effects on several marine and soil bacteria, green algae, and duckweed but stated that many more data were needed with respect to long-term, chronic, and synergistic effects. [4]. To minimize environmental hazards, various technologies are being explored worldwide for the implementation of an advanced purification extension to WWTPs, such as the use of activated carbon, bioreactors, membrane reactors, or constructed wetlands [7,8]. Another approach is the use of Advanced Oxidation Processes (AOPs) [9-11]. These comprise ozonation, UV radiation treatment, and the use of photocatalysts such as Photo-Fenton, hydrogen peroxide or titanium dioxide. A recent 
comprehensive survey on the UV based processes and their technical upscaling was conducted by Collivignarelli et al. [12]. The AOPs lead to the formation of hydroxyl radicals that are able to destroy organic micropollutants, but the hydroxyl radicals can also attach themselves to the substances, leading to even more hazardous products $[13,14]$.

Unfortunately, reference standards are very rarely or not at all available for the characterization of the degradation products resulting from these processes. Their synthesis is often costly and complex. As a consequence, only inadequate toxicity data are retrievable for such degradation products. This is also the case for metoprolol. A cost-effective option is quantitative structure-activity relationship (QSAR) analysis $[15,16]$. QSAR relates the molecular structure with its pharmacological, physico-chemical, toxicological, or ecotoxicological effects. For this purpose, a correlation or a model is created from various data that resulted from in vitro or in vivo ecotoxicologically relevant assays on organisms specific for the environmental compartment. Based on the model established from chemometric or mathematical methods, such as linear regression types, artificial intelligence and machine learning algorithms, ecotoxicity or other sought parameters of not-tested compounds or novel putative molecular structures are predicted.

In this study, solutions of metoprolol were exposed to UV-irradiation at different $\mathrm{pH}$ values in the presence and absence of hydrogen peroxide. The resulting degradation and transformation products were identified using high-performance liquid-chromatography coupled with high-resolution mass spectrometry (HPLC-HRMS). Their concentrationtime curves were monitored and analyzed by chemical kinetics. In addition, ozonation of metoprolol was performed in saturated ozone solution and under continuous ozone flow. The AOPs and different conditions were compared with respect to the resulting degradation and transformation products. For the UV-irradiation and ozonation products, QSAR analysis was performed using OECD QSAR toolbox (https://qsartoolbox.org/; accessed on 14 May 2021) and VEGA software (https:/ / www.vegahub.eu/; accessed on 14 May 2021) and the ecotoxicity predicted [17-20].

Results from both prediction tools were critically discussed as to the suitability of the AOP for metoprolol elimination from the aquatic environment.

The ecotoxicity of individual degradation or transformation products is often impossible to evaluate experimentally, since standards for the identified products cannot be bought and the synthesis is too expensive. It is also often not known what long-term effects the substances will exercise on the microorganisms. In these cases, QSAR analysis offers a suitable means to predict ecotoxicological potential.

\section{Materials and Methods}

\subsection{Chemicals and Reagents}

Metoprolol tartrate was acquired from Alfa Aesar (98\%, Karlsruhe, Germany) and used for all degradation experiments. The eluents for HPLC were A MilliQ water (Millipore System Simplicity 185) and B acetonitrile (99.95\%, Carl Roth GmbH + Co. KG, Karlsruhe, Germany), both acidified with formic acid (98-100\%, Merck KGaA, Darmstadt, Germany) to $0.1 \%$ final concentration. Sample solutions were prepared containing $20 \mathrm{mg} \mathrm{L}^{-1}$ metoprolol in MilliQ water. For $\mathrm{pH}$ dependent assays, the $\mathrm{pH}$ was adjusted with hydrochloric acid ( $\mathrm{HCl}, 30 \%$ Suprapur, Merck KGaA, Darmstadt, Germany) or ammoniacal solution $\left(\mathrm{NH}_{3}\right.$, approximately $25 \%$ Riedel-de Haen, Seelze, Germany).

\subsection{Photodegradation Experiments}

Photoinduced degradation experiments were carried out in a $1 \mathrm{~L}$ batch reactor (Peschl Ultraviolet $\mathrm{GmbH}$, Mainz, Germany). A mercury low pressure VUV/UVC lamp (Heraeus TNN 15/32, 15 W, Hanau, Germany) was located in the middle of the reactor. The UVC lamp emitted polychromatic light whose maximum radiation intensities were found at wavelengths $185,254,313,365,405,437,547,578$, and $580 \mathrm{~nm}$. The total flux of photons in the wavelength range between 200 and $500 \mathrm{~nm}$ was determined by means of ferrioxalate actinometry according to Kuhn et al. and Hatchard et al. and amounted to 
$2.03 \mathrm{mmol} \cdot \mathrm{min}^{-1} \cdot \mathrm{L}^{-1}[21,22]$. The occurrence of hydroxyl radicals on irradiation of water was proven by Electron Spin Resonance (ESR) spectroscopy using spin traps (data not shown) according to Kochany et al. $[23,24]$.

The reactor was filled with $800 \mathrm{~mL}$ of the metoprolol solution. Irradiation with UVC light was applied for $10 \mathrm{~min}$. A magnetic stirrer (500 rpm) was used for continuous homogenization in the reactor. The reaction temperature throughout the reactor was $22 \pm 2{ }^{\circ} \mathrm{C}$ and was checked during degradation by means of a thermometer. Samples were taken every $30 \mathrm{~s}$ during five minutes and every minute until ten minutes.

The photocatalytic degradation of metoprolol was carried out using hydrogen peroxide (30\% stabilized, Carl Roth GmbH + Co. KG, Karlsruhe, Germany) that was added to the metoprolol solutions such that concentrations of $10 \mathrm{mg} \cdot \mathrm{L}^{-1}$ and $30 \mathrm{mg} \cdot \mathrm{L}^{-1}$ resulted. Peroxide concentration were determined using Merckoquant test strips (Merck KGaA, Darmstadt, Germany) before and after irradiation.

\subsection{Ozonation}

A 1 L-batch reactor (DWK Life Sciences, Wertheim, Germany) was used for ozonation experiments. Ozone was produced using a COM-AD-01/02 ozone generator (Anseros, Tuebingen, Germany). The oxygen flow was set to $25 \mathrm{~L} \cdot \mathrm{h}^{-1}$ and the generator capacity was $2.8 \%$. The ozone flow was continuously led through a glass frit into the reactor containing $1 \mathrm{~L}$ of a metoprolol solution with a concentration of $20 \mathrm{mg} \cdot \mathrm{L}^{-1}$. Ozonation proceeded for $30 \mathrm{~min}$ while stirring the solution at $500 \mathrm{rpm}$. Samples were taken every minute. For experiments in ozone-saturated solution, $0.5 \mathrm{~L}$ MilliQ water were treated with ozone for 18 min prior to metoprolol addition. Levels of saturation were checked photometrically. A stock solution of metoprolol was added to the solution such that a final metoprolol concentration of $20 \mathrm{mg} \cdot \mathrm{L}^{-1}$ was achieved. Samples were taken every second minute. In all experiments, temperature was kept at $23 \pm 2{ }^{\circ} \mathrm{C}$.

\subsection{HPLC-HRMS}

Reversed-phase chromatographic analysis was performed using a Agilent 1200 Series HPLC system (Agilent Technologies, Inc., Waldbronn, Germany) equipped with an Eclipse Plus C18 (ZORBAX, $3.5 \mu \mathrm{m}, 2.1 \times 150$ mm, Agilent Technologies, Inc., Waldbronn, Germany). A flow rate of $0.3 \mathrm{~mL} \mathrm{~min}-1$ and a column temperature of $40{ }^{\circ} \mathrm{C}$ were used. Elution started with eluents A and B going from 99:1 to 70:30 within 1 min, followed by isocratic conditions of $A$ and B 25:75 during the next $10 \mathrm{~min}$. At $11.1 \mathrm{~min}$, the solvent composition was set to $1: 99$ and hold for $0.1 \mathrm{~min}$. At minute 15, the gradient was reset to starting conditions and held for further $15 \mathrm{~min}$. For structure identification and recording concentration-time $(c-t)$ curves, the HPLC system was coupled to an electrospray ionization (ESI) quadrupole time-of-flight mass spectrometer Agilent 6530 (Q-TOF-MS, Agilent Technologies, Inc., Waldbronn, Germany) with a Dual AJS electrospray ionization interface. The interface capillary temperature was set to $300{ }^{\circ} \mathrm{C}$ and the gas flow to $8 \mathrm{~L} \cdot \mathrm{min}^{-1}$. The fragmentor voltage was set to $125 \mathrm{~V}$. Spectra were recorded in the positive ion mode with a mass range from 100 to $1000 \mathrm{~m} / z$ at a scan rate of 1 spectrum s${ }^{-1}$. Both instruments were controlled using MassHunter Workstation B.06.00 (Agilent Technologies, Inc., Waldbronn, Germany).

\subsection{Kinetic Analysis of the Photodegradation}

The degradation curves and kinetic profiles of the degradation products were calculated and fitted mathematically using the curve fitting toolbox within the software MatLab R2020a (MathWorks, Natick, MA, USA). All kinetic profiles and degradation curves were computed according to first-order kinetic models, consecutive and subsequent follow-up reaction models [25-29]. 


\subsection{Assessment of Ecotoxicology}

For QSAR analysis, the software OECD QSAR Toolbox 4.3.1 and the software VEGA version 1.1.5-b36 were used. Calculations in the QSAR Toolbox were based on the Ecological Structure Activity Relationships (ECOSAR) predictive model for aquatic toxicity. For acute ecotoxicity $\left(\mathrm{LC}_{50}\right.$ and $\left.\mathrm{EC}_{50}\right)$ and chronic toxicity $(\mathrm{ChV})$ prediction, the organisms branchiopoda, Actinopterygii, and green algae were selected. In addition, a model developed by Veith et al. and Pavan et al. was implemented in the OECD QSAR toolbox $[17,18]$. From this model, fathead minnow and acute toxicity $\left(\mathrm{LC}_{50}\right)$ were chosen. Acute and chronic toxicity were also predicted using VEGA Version 1.1.5-b36. Models from the Instituto di Ricerche Farmacologiche Mario Negri (IRFMN) in Milan, Italy, the United States Environmental Protection Agency (EPA), National Institute of Chemistry (NIC), the project "Development of Environmental Modules for Evaluation of Toxicity of pesticide Residues in Agriculture" (DEMETRA), KNN Read across and ProtoQSAR were included therein. Fish in general, fathead minnow, Daphnia magna and algae were selected as representative organisms for the assessment of aquatic toxicity.

\section{Results and Discussion}

\subsection{Photoinduced Degradation of Metoprolol-Kinetic Modelling of Degradation}

The concentration of metoprolol decreased upon UV irradiation. Concentrationtime curves $(c-t)$ showed a degradation, which could be best described by using first or pseudo-first order chemical kinetics $[10,28,29]$. The addition of hydrogen peroxide led to accelerated degradation. The corresponding $c$ - $t$ curves with increasing concentrations of $\mathrm{H}_{2} \mathrm{O}_{2}$ are given in Figure 1.

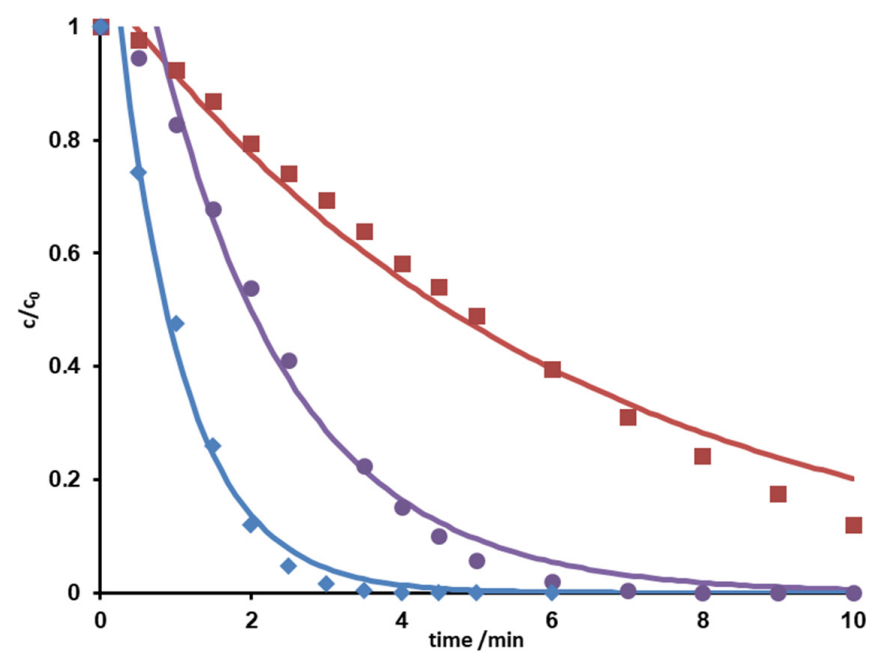

Figure 1. Normalized concentration-time curves of metoprolol (red, $\mathbf{\square})$, in the presence of $10 \mathrm{mg} \cdot \mathrm{L}^{-1}$ $\mathrm{H}_{2} \mathrm{O}_{2}$ (violet, $\bullet$ ) and $30 \mathrm{mg} \cdot \mathrm{L}^{-1} \mathrm{H}_{2} \mathrm{O}_{2}$ (blue, $\diamond$ ).

It can be clearly seen that increasing hydrogen peroxide concentrations favor the elimination of metoprolol. Reaction rate constants and half-lives indicated an acceleration by a factor of about 6 , cf. Table 1 .

Table 1. Reaction rate constants and their half-lives of the degradation of metoprolol at $\mathrm{pH} 3,6$, and 9, and upon addition of $\mathrm{H}_{2} \mathrm{O}_{2}$.

\begin{tabular}{cccc}
\hline pH & $\mathbf{H}_{\mathbf{2}} \mathbf{O}_{\mathbf{2}} / \mathbf{m g ~ L}^{-\mathbf{1}}$ & $k / \mathbf{m i n}^{-1}$ & $t \frac{1}{2} / \mathbf{m i n}$ \\
\hline 3 & - & 0.20 & 3.44 \\
6 & - & 0.18 & 3.76 \\
9 & - & 0.18 & 3.94 \\
6 & 10 & 0.55 & 1.26 \\
6 & 30 & 1.14 & 0.61 \\
\hline
\end{tabular}


The complete degradation of metoprolol was observed after 4.5 min UVC irradiation in the presence of $30 \mathrm{mg} \cdot \mathrm{L}^{-1}$ hydrogen peroxide. This was traced back to the increase of the hydroxyl radical concentration resulting from photolysis of hydrogen peroxide. Increasing the $\mathrm{pH}$ from acid to basic caused a slight deceleration of the photo-induced degradation.

\subsection{Photoinduced Degradation of Metoprolol-Product Characterization}

Despite the different photoinduced degradation conditions, similar main intermediate products were observed. Photoinduced degradation follows two major mechanisms: either photolysis by absorption of radiation, excitation and photoreaction, or reaction with hydroxyl radicals formed from UV light induced hydrolysis. A list of all observed and structurally identified intermediates are collected in Table 2.

Table 2. Photoinduced transformation products of metoprolol: Retention times, exact and accurate mass, and structure proposal.

\begin{tabular}{|c|c|c|c|c|}
\hline Retention Time/min & {$[\mathrm{M}+\mathrm{H}]^{+}$(exact) } & {$\left[\mathrm{M}+\mathrm{H}^{+}{ }^{+}\right.$(accurate) } & Proposed Structure & Reference \\
\hline 5.1 & 268.1907 & 268.1831 & & Metoprolol \\
\hline $2.9 ; 3.4 ; 4.1$ & 284.1856 & 284.1796 & & {$[30-40]$} \\
\hline $4.8 ; 5.0$ & 282.1700 & 282.1612 & & {$[30-34,36-41]$} \\
\hline 3.9 & 254.1387 & 254.1638 & & {$[30-35,37,38,40,41]$} \\
\hline 4.2 & 252.1594 & 252.1533 & & {$[30,31,33,34,37,38,40]$} \\
\hline 4.1 & 238.1438 & 238.1379 & & {$[30,31,33-40,42]$} \\
\hline 1.4 & 134.1176 & 134.1127 & & {$[30-32,34-41,43]$} \\
\hline
\end{tabular}

Products from both mechanisms could be identified. The absorption pathway led to degradation products possessing smaller masses, such as the product with $m / z=134$ and 252. The second mechanism resulted in products with higher masses due to the addition or insertion of hydroxyl radicals, such as $m / z=284,282$ and 254 . These products would be degraded further. Mainly hydroxyl radical induced degradation products were observed. Products with $m / z=284$ and $m / z=282$ were found at different retention times. This is indicative for isomers, as the addition or insertion may take place at different positions. Further investigations using $\mathrm{MS}^{\mathrm{n}}$ experiments are required for elucidation of the isomers as was described earlier $[32,34,35,38,40,44-46]$. The addition and insertion of hydroxyl radicals seemed to occur predominantly at the aromatic ring and the adjacent carbon atoms. This is in agreement with preliminary results of quantum-chemical calculations showing that the highest electron density includes that region and the highest occupied molecular 
orbital (HOMO) and the lowest unoccupied molecular orbital (LUMO) extend over that region. Hence, oxidation should be favored there.

The $c-t$ diagrams of the degradation and transformation products at $\mathrm{pH} 6$ in the presence and absence of hydrogen peroxide are displayed in Figure 2.

a)

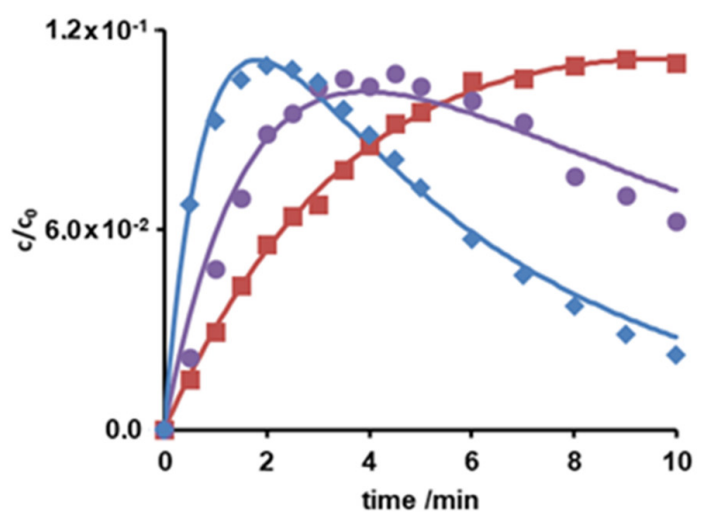

c)

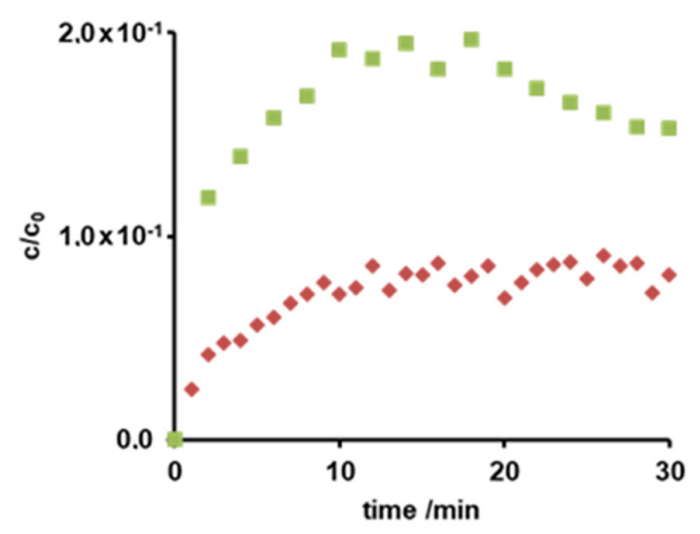

b)

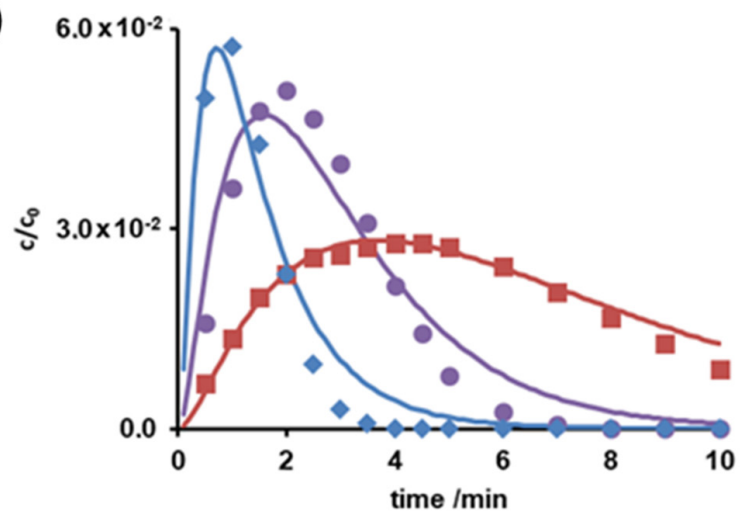

d)

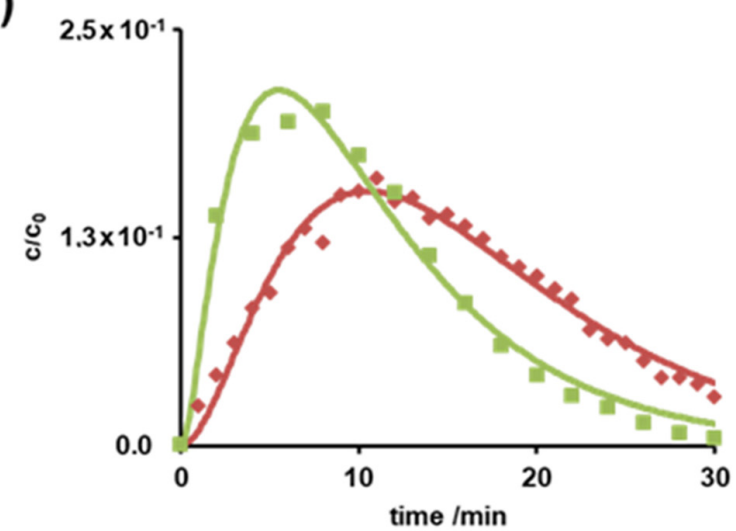

Figure 2. Normalized $c$ - $t$-curves of photoinduced degradation products with (a) $\mathrm{m} / z=134$ and (b) $\mathrm{m} / \mathrm{z}=284 \mathrm{RT} 4.1 \mathrm{~min}$ with $0 \mathrm{mg} \mathrm{L}^{-1} \mathrm{H}_{2} \mathrm{O}_{2}$ (red, $\mathbf{\square}$ ), with $10 \mathrm{mg} \mathrm{L}^{-1} \mathrm{H}_{2} \mathrm{O}_{2}$ (violet, $\bullet$ ) and $30 \mathrm{mg} \mathrm{L}^{-1} \mathrm{H}_{2} \mathrm{O}_{2}$ (blue, $\bullet$ ) and normalized c- $t$-curves of degradation or transformation products through ozonation with (c) $\mathrm{m} / z=134$ and (d) $\mathrm{m} / \mathrm{z}=300$ RT 5.4 min using ozone flow (red, $\downarrow$ ) and in ozone-saturated solution (green, $\mathbf{\square})$.

The recorded $c$ - $t$-curves were best described by sequence or subsequence follow-up reaction of first-order $[25,28]$.

As for the initial compound, hydrogen peroxide induced a faster increase and decrease of the products. Almost all products occurred and vanished within $10 \mathrm{~min}$, except for that with $m / z=134$. The products with $m / z=134$ and 284 are exemplarily shown. In summary, photo-irradiation in combination with hydrogen peroxide proved efficient both for metoprolol itself and for the secondary products.

\subsection{Ozonation of Metoprolol}

The $c$ - $t$ curves of the degradation of metoprolol upon ozonation are shown in Figure 3.

Monitoring of metoprolol degradation when the compound was added to a previously ozone-saturated solution and when bubbling ozone through a metoprolol containing solution led to different reaction rate constants. As expected, the pre-saturated ozone solution caused a faster degradation. A reaction rate of $0.19 \mathrm{~min}^{-1}$ was found while a rate constant of $0.12 \mathrm{~min}^{-1}$ was observed in case of ozone bubbling. Both $c$ - $t$ curves were fitted using pseudo-first order kinetics since ozone was assumed in excess.

The same degradation or transformation products were identified as would be expected. An overview of the predominantly formed products is given in Table 3 . 


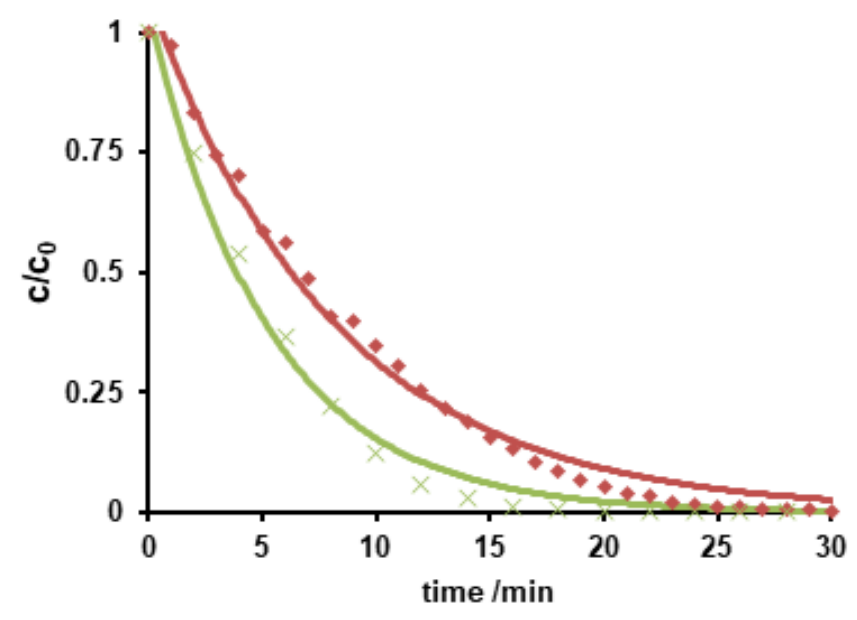

Figure 3. Normalized $c$-t-curves of ozonation of metoprolol using ozone-flow (red, $\downarrow$ ) and in ozonesaturated solution (green,

Table 3. Ozonation products of metoprolol: Retention times, exact and accurate mass, and structure proposal.

\begin{tabular}{|c|c|c|c|c|}
\hline Retention Time/min & {$[\mathrm{M}+\mathrm{H}]^{+}{ }_{(\text {exact })}$} & {$[\mathrm{M}+\mathrm{H}]^{+}{ }_{\text {(accurate) }}$} & Proposed Structure & Reference \\
\hline 5.9 & 268.1907 & 268.1872 & & Metoprolol \\
\hline $5.3 ; 5.4$ & 300.1805 & 300.1770 & & {$[30,31,34,39,40,47-49]$} \\
\hline $5.2 ; 5.8$ & 282.1700 & 282.1703 & & {$[30-34,36-41,45]$} \\
\hline $5.2 ; 5.3$ & 274.1649 & 274.1615 & & {$[47,48]$} \\
\hline 1.8 & 206.1023 & 206.0991 & & {$[34,48]$} \\
\hline 1.4 & 134.1176 & 134.1150 & & {$[30-32,34-41,43,48,49]$} \\
\hline
\end{tabular}

As compared to photo-induced degradation, identical products such as $m / z=282$ and $m / z=134$ were found. Yet, different products, such as $m / z=300, m / z=274$ and $m / z=206$, were identified as well. Interestingly, structures with the aromatic ring opened were observed, e.g., $m / z=274$ and 206. Products with higher molecular weight than metoprolol were detected more often than after irradiation.

The concentration of the secondary products was higher when metoprolol was added to an ozone-saturated solution. Thus, formation occurred seemingly faster followed by degradation, since reactions in the ozone-saturated solution were likely limited by mass transfer, whereas degradation in the presence of ozone-flow follow molecular kinetics. In addition, secondary compounds, that were formed, $m / z=134$ (Figure 2c) and 206 (data not shown), but did not react further within $30 \mathrm{~min}$, were observed. In contrast, products with $m / z=282$ (data not shown) and 300 (Figure 2d) were formed and disappeared within $30 \mathrm{~min}$. Comparison of all $c$ - $t$ curves suggested that for the elimination of metoprolol and its degradation products, UV-irradiation in combination with hydrogen peroxide might 
be the more efficient AOP. With respect to installation in WWTP, UV-irradiation based technical processes often suffer from high capital and operative costs and the limited or absent experience of full-scale plant management [12].

\subsection{Assessment of Ecotoxicity with QSAR Analysis}

Prediction of toxicological and ecotoxicological parameters by QSAR is based on structural similarity. Hence, goodness of prediction heavily depends on the number of similar entries and their consistency. A recent study critically assessed in silico ecotoxicity prediction by comparison with in vitro testing [50]. In the current study, both QSAR software packages relied on the Simplified Molecular Input Line Entry System (SMILESTM, https://www.daylight.com/smiles/index.html; accessed on 14 May 2021), which does not recognize tautomers due to the coding system and only takes stereochemistry into account in an extended version. Since hydroxyl addition or insertion may lead to regio-isomers and quinoid-like structures with metoprolol, isomers of the above-described degradation products were sketched and submitted to QSAR analysis. All structures presented in Tables 2 and 3 were tested. Structures tested as isomers are shown in Figure 4.
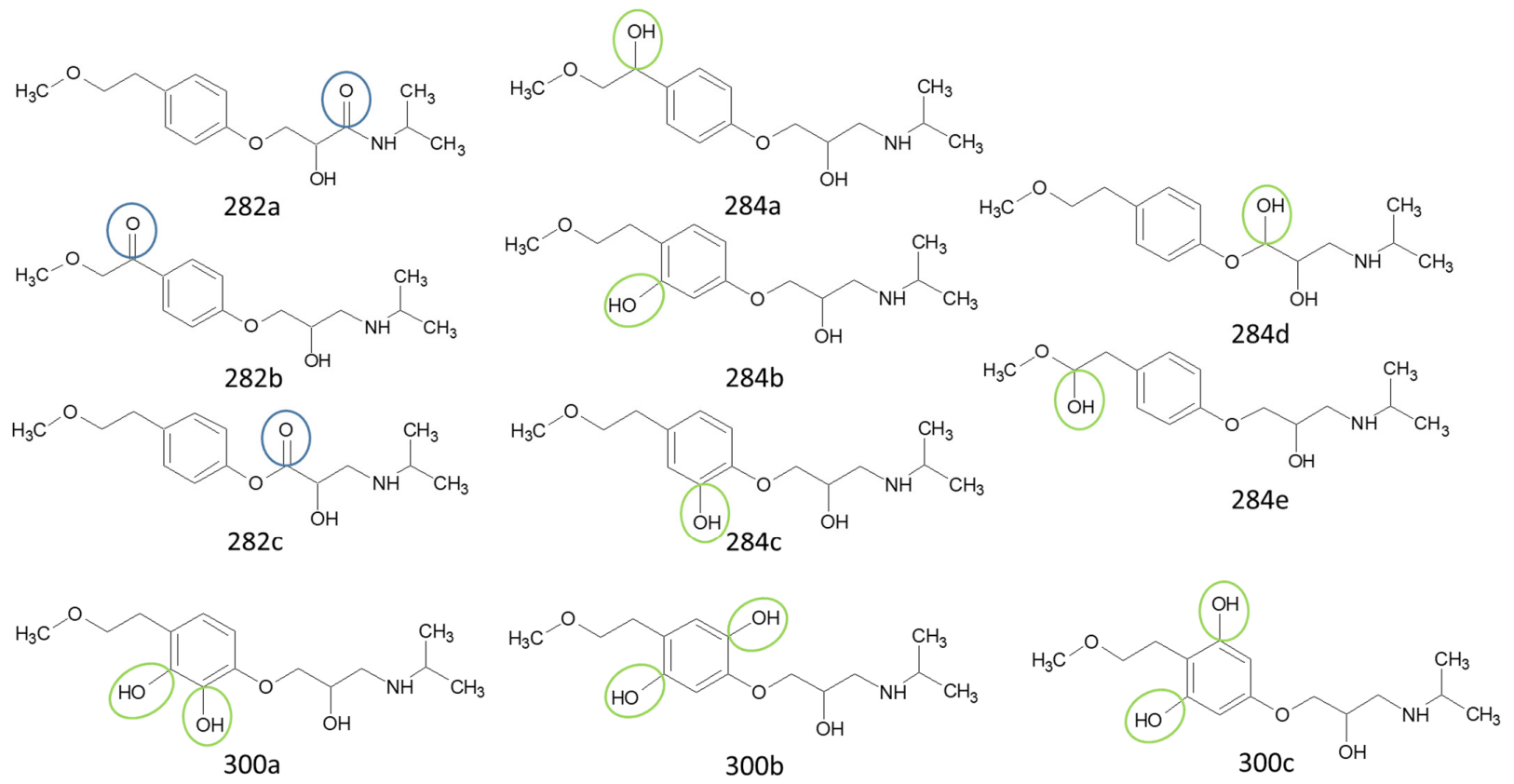

Figure 4. Structure proposals of degradation and transformation products from UV-irradiation and ozonation as used for QSAR analysis. Numbers correspond to rounded $m / z$ values, index letters refer to isomers.

The results of ecotoxicity prediction using the OECD QSAR toolbox are listed in Table 4. According to the prediction, all products of photo-induced and hydroxyl radical induced degradation exhibited lower toxicity both acute and chronic against daphnid, fish, green algae, and Pimephales promelas, since the lethal concentrations $\left(\mathrm{LC}_{50}\right)$ of all products were higher than that of metoprolol. Based on these results, no hazard to the aquatic environment should be expected when using UV radiation in the presence or absence of hydrogen peroxide to eliminate metoprolol. Among the ozonation products, only the product $m / z=206$ was found to be of higher ecotoxicity to all organisms. As can be seen, isomers were predicted with different ecotoxicity. In case of structure family 300 , hydroquinoid moieties within $300 \mathrm{a}$ and $300 \mathrm{~b}$ provoked slightly lower toxic values than the meta-substituent arrangement within 300c. For the isomers of 282, the keto group was associated with less hazardous potential than the ester function, while for the amid isomer, no value was computed for branchiopoda, fish, and green algae. In general, larger and higher species seemed less prone to the adverse effects of metoprolol and its degradation or transformation products. 
Table 4. QSAR analysis of metoprolol and with less (green) and more hazardous (red) degradation and transformation products from UV irradiation and ozonation using the OECD-QSAR toolbox.

\begin{tabular}{|c|c|c|c|c|c|c|c|c|c|c|}
\hline & \multicolumn{2}{|c|}{$\begin{array}{c}\text { Daphnid } \\
\text { (Branchiopoda) }\end{array}$} & \multicolumn{2}{|c|}{ Fish (Actinopterygii) } & \multicolumn{2}{|c|}{ Green Algae } & \multicolumn{4}{|c|}{ Pimephales promelas (Fathead Minnow) } \\
\hline & $\begin{array}{c}48 \mathrm{~h} \\
\mathrm{LC}_{50} / \mathrm{mg} \cdot \mathrm{L}^{-1}\end{array}$ & $\underset{/ \mathrm{mg} \cdot \mathrm{L}^{-1}}{\mathrm{ChV}}$ & $\begin{array}{c}96 \mathrm{~h} \\
\mathrm{LC}_{50} / \mathrm{mg} \cdot \mathrm{L}^{-1}\end{array}$ & $\begin{array}{c}\mathrm{ChV} \\
/ \mathrm{mg} \cdot \mathrm{L}^{-1}\end{array}$ & $\begin{array}{l}96 \mathrm{~h} \mathrm{EC} \\
/ \mathrm{mg} \cdot \mathrm{L}^{-1}\end{array}$ & $\begin{array}{c}\mathrm{ChV} \\
/ \mathrm{mg} \cdot \mathrm{L}^{-1}\end{array}$ & $\underset{\mathrm{LC}_{50} / \mathrm{mg} \cdot \mathrm{L}^{-1}}{\mathrm{M} 1-}$ & $\underset{\mathrm{LC}_{50} / \mathrm{mg} \cdot \mathrm{L}^{-1}}{\mathrm{M} 2-}$ & $\frac{\mathrm{M} 3-}{\mathrm{LC}_{50} / \mathrm{mg} \cdot \mathrm{L}^{-1}}$ & $\frac{\mathrm{M} 4-}{\mathrm{LC}_{50} / \mathrm{mg} \cdot \mathrm{L}^{-1}}$ \\
\hline Meto-prolol & 9.44 & 0.75 & 82.1 & 5.33 & 8.36 & 2.71 & 144 & 208 & 437 & 111 \\
\hline 134 & 170 & 10.1 & $2 \times 10^{3}$ & 322 & 272 & 71.0 & $3.04 \times 10^{4}$ & $1.25 \times 10^{4}$ & $3.57 \times 10^{4}$ & $3.99 \times 10^{3}$ \\
\hline 206 & 2.88 & 0.25 & 23.2 & 1.20 & 2.20 & 0.75 & N.p. & 46.8 & 90.9 & 28.4 \\
\hline 238 & 15.5 & 1.17 & 142 & 10.8 & 15.2 & 4.73 & 228 & 420 & 928 & 205 \\
\hline 252 & 17.8 & 1.34 & 164 & 12.8 & 17.7 & 5.50 & 161 & 497 & $1.11 \times 10^{3}$ & 240 \\
\hline 254 & 94.7 & 6.21 & $1 \times 10^{3}$ & 119 & 124 & 34.8 & N.p. & $4.61 \times 10^{3}$ & $1.18 \times 10^{4}$ & $1.75 \times 10^{3}$ \\
\hline 274 & 107 & 6.96 & $1.13 \times 10^{3}$ & 135 & 140 & 39.3 & N.p. & $5.26 \times 10^{3}$ & $1.36 \times 10^{4}$ & $1.99 \times 10^{3}$ \\
\hline $282(\mathrm{a})$ & N.p. & N.p. & N.p. & N.p. & N.p. & N.p. & N.p. & $1.44 \times 10^{3}$ & $3.41 \times 10^{3}$ & 627 \\
\hline $282(\mathrm{~b})$ & 65.4 & 4.46 & 666 & 69.8 & 79.1 & 22.8 & N.p. & $2.72 \times 10^{3}$ & $6.7 \times 10^{3}$ & $1.11 \times 10^{3}$ \\
\hline 282 (c) & 38.5 & 2.74 & 375 & 34.3 & 42.6 & 12.7 & N.p. & $1.34 \times 10^{3}$ & $3.15 \times 10^{3}$ & 587 \\
\hline 284 (a) & 48.5 & 3.38 & 481 & 46.6 & 55.7 & 16.4 & N.p. & $1.81 \times 10^{3}$ & $4.36 \times 10^{3}$ & 772 \\
\hline 284 (b) & 19.6 & 1.47 & 180 & 13.9 & 19.4 & 6.01 & N.p. & 540 & $1.2 \times 10^{3}$ & 262 \\
\hline 284 (c) & 27.7 & 2.03 & 262 & 22.1 & 29.1 & 8.84 & N.p. & 860 & $1.97 \times 10^{3}$ & 397 \\
\hline $284(d)$ & 48.5 & 3.38 & 481 & 46.6 & 55.7 & 16.4 & N.p. & $1.81 \times 10^{3}$ & $4.36 \times 10^{3}$ & 772 \\
\hline $284(\mathrm{e})$ & 48.5 & 3.38 & 481 & 46.6 & 55.7 & 16.4 & N.p. & $1.81 \times 10^{3}$ & $4.36 \times 10^{3}$ & 772 \\
\hline 300 (a) & 57.3 & 3.96 & 573 & 57.2 & 67 & 19.6 & N.p. & $2.23 \times 10^{3}$ & $5.40 \times 10^{3}$ & 931 \\
\hline $300(b)$ & 57.3 & 3.96 & 573 & 57.2 & 67 & 19.6 & N.p. & $2.23 \times 10^{3}$ & $5.40 \times 10^{3}$ & 931 \\
\hline 300 (c) & 40.4 & 2.87 & 393 & 35.9 & 44.6 & 13.3 & N.p. & $1.4 \times 10^{3}$ & $3.29 \times 10^{3}$ & 614 \\
\hline
\end{tabular}

N.p. = Not predicted; other abbreviations given in the Experimental Section.

To compare the variation of prediction, Table 5 lists the corresponding values computed using VEGA. A total of 10 models were used within the OECD QSAR toolbox. Models based on the ECOSAR database employed structure specific training sets, whereas the model by Veith et al. and Pavan et al. relied on training sets and validation sets. As of today, the available data basis is limited. Exemplarily, the implemented data sets for acute toxicity prediction ranged from 22 to 83 , for chronic toxicity from 3 to 13 points. The models by Veit et al. and Pavan et al. contained between 58 and 144 datasets. The goodness-of-fit could be determined by using training sets. The coefficients of determination were between 0.78 and 0.92 . Using VEGA, some products, such as $m / z=252$, were classified more toxic. The products with $\mathrm{m} / z=284$ and the one with $\mathrm{m} / z=134$ were predicted less toxic for most species, while no uniform trend could be identified for the other products. In contrast to the OECD QSAR toolbox prediction, the ozonation product was computed to be less ecotoxic. Furthermore, the evaluation of the isomers deviated as well. For the 300 family, the meta-isomer was considered less ecotoxic than the hydroquinoid isomers. The same applied for the 282 series. The amid isomer 282a could be predicted and was judged to be more hazardous than the keto isomer 282b. In VEGA, a total of 15 different models were used for the ecotoxicity prediction. They contained in general several hundred data on the ecotoxicity of various substances, from which the desired models are created. The larger amount of data allowed the prediction of the structure missing with the OECD toolbox. As a drawback, both toolboxes did not contain relevant experimental data on metoprolol nor on the transformation products as such. Similar compounds, however, were indicated. Yet, both toolboxes employed quality criteria mainly based on statistical parameters, which were retrieved in the QSAR model report format (QMRF). Which of the predictions would be more reliable could not be distinguished but would require experimental data, especially when different quality criteria were listed. Hence, the number of similar structures and consistent values used for model building and prediction is probably one of the most direct quantities for reliability evaluation, despite the deficiencies of the SMILES ${ }^{\mathrm{TM}}$ coding. In conclusion, both predictive tools yield qualitatively comparable results in general. Yet, uncommon and rare structures or novel compound classes lead to no or contradictory results. Nevertheless, a preliminary estimation of potential hazards from compounds putatively emerging during AOP induced elimination of micropollutants should be feasible. The results may be applied to evaluate the effectiveness of the AOP to remove conventionally hard-to-eliminate pharmaceuticals or other pollutants from wastewater effluents. To this purpose, the extension of ecotoxicological databases is necessary. 


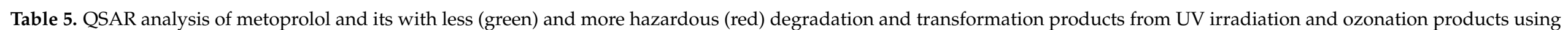
VEGA QSAR.

\begin{tabular}{|c|c|c|c|c|c|c|c|c|c|c|c|c|c|c|c|}
\hline & \multicolumn{5}{|c|}{ Fish } & \multicolumn{2}{|c|}{ Fathead Minnow } & \multicolumn{5}{|c|}{ Daphnia Magna } & \multicolumn{3}{|c|}{ Algae } \\
\hline & \multicolumn{4}{|c|}{ Acute $\left(\mathrm{LC}_{50}\right) / \mathrm{mg} \cdot \mathrm{L}^{-1}$} & \multirow{2}{*}{ 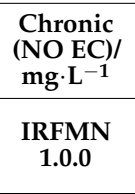 } & \multirow{2}{*}{$\begin{array}{c}\begin{array}{c}\mathrm{LC}_{50} \\
96 \mathrm{~h} / \\
\mathrm{mg} \cdot \mathrm{L}^{-1}\end{array} \\
\text { EPA } 1.0 .7\end{array}$} & \multirow{2}{*}{$\begin{array}{c}\mathrm{LC}_{50} / \mathrm{mg} \cdot \mathrm{L}^{-1} \\
\mathrm{KNN} / \mathrm{IRFMN} \\
\mathbf{1 . 1 . 0}\end{array}$} & \multicolumn{2}{|c|}{$\begin{array}{l}\mathrm{LC}_{50} 48 \mathrm{~h} \\
/ \mathrm{mg} \cdot \mathrm{L}^{-1}\end{array}$} & \multicolumn{2}{|c|}{ Acute $\left(\mathrm{EC}_{50}\right) / \mathrm{mg} \cdot \mathrm{L}^{-1}$} & \multirow{2}{*}{$\begin{array}{c}\begin{array}{c}\text { Chronic } \\
\text { (NOEC)/ } \\
\text { mg. } \text { L }^{-1}\end{array} \\
\text { IRFM } \\
\mathbf{1 . 0 . 0}\end{array}$} & \multicolumn{2}{|c|}{$\begin{array}{l}\text { Acute }\left(\mathrm{EC}_{50}\right) / \\
\mathrm{mg} \cdot \mathrm{L}^{-1}\end{array}$} & \multirow{2}{*}{$\begin{array}{c}\begin{array}{c}\text { Chronic } \\
\left(\text { NOEC)/mg } \text { L }^{-1}\right.\end{array} \\
\text { IRFMN } 1.0 .0\end{array}$} \\
\hline & $\begin{array}{c}\text { KNN/Read- } \\
\text { Across } \\
1.0 .0\end{array}$ & NIC 1.0.0 & $\begin{array}{l}\text { IRFMN } \\
1.0 .0\end{array}$ & $\begin{array}{c}\text { IRFMN/ } \\
\text { Combase } \\
1.0 .0\end{array}$ & & & & EPA 1.0.7 & $\begin{array}{c}\text { DEMETRA } \\
\mathbf{1 . 0 . 4}\end{array}$ & $\begin{array}{c}\text { IRFMN } \\
1.0 .0\end{array}$ & $\begin{array}{c}\text { IRFMN/ } \\
\text { Combase } \\
1.0 .0 \\
\end{array}$ & & $\begin{array}{l}\text { IRFMN } \\
1.0 .0\end{array}$ & $\begin{array}{c}\text { ProtoQSAR/ } \\
\text { Combase } \\
1.0 .0\end{array}$ & \\
\hline Metoprolol & 13.8 & 1.1 & 5.0 & 2.3 & 0.18 & 73.9 & 3.8 & 2.3 & 2.22 & 170 & $5.7 \times 10^{-3}$ & 7.96 & 4.6 & 57.70 & 1.03 \\
\hline 134 & 4019.8 & 512.0 & 15.6 & 268.5 & 3.40 & 1650.8 & 4091.4 & 1434.4 & 25.63 & 154 & 2.5 & 7.11 & 53.3 & 3.15 & 15.42 \\
\hline 206 & 3056.1 & 93.7 & 17.4 & 64.1 & 0.65 & 694.1 & N.p. & 6727.0 & 393.32 & 102 & 1.11 & 10.4 & 21.2 & 26.84 & 18.96 \\
\hline 238 & 13.0 & 3.4 & 4.7 & 3.2 & 0.25 & 102.6 & 13.5 & 4.7 & 7.51 & 44 & $1.4 \times 10^{-2}$ & 7.72 & 5.3 & 0.85 & 2.17 \\
\hline 252 & 16.7 & 3.6 & 5.4 & 1.7 & 0.15 & 40.7 & 12.7 & 50.6 & 6.32 & 4 & $3.3 \times 10^{-3}$ & 7.73 & 4.1 & 0.74 & 1.52 \\
\hline 254 & 28.0 & 5.2 & 4.5 & 2.5 & 0.29 & 14.6 & 27.0 & 64.1 & 47.49 & 450 & 0.18 & 7.39 & 9.9 & 0.08 & 1.09 \\
\hline 274 & 1.76 & 19.9 & 3.31 & 3.0 & 0.31 & 222.1 & 0.6 & 9.0 & 6.5 & 751 & 0.36 & 9.18 & 8.0 & 101.64 & 1.78 \\
\hline 282 (a) & 14.0 & 1.1 & 8.7 & 1.8 & 0.19 & 63.8 & 4.1 & 1.9 & 6.20 & 217 & $1.9 \times 10^{-2}$ & 10.09 & 4.9 & 63.79 & 1.16 \\
\hline $282(b)$ & 21.7 & 1.1 & 5.2 & 2.8 & 0.18 & 88.6 & 4.5 & 2.2 & 7.43 & 285 & $1.7 \times 10^{-2}$ & 11.16 & 4.4 & 0.69 & 0.98 \\
\hline $282(\mathrm{c})$ & 29.6 & 1.1 & 7.9 & 3.0 & 0.20 & 47.1 & 13.0 & 1.9 & 1.41 & 188 & $4.9 \times 10^{-3}$ & 8.77 & 4.7 & 0.67 & 1.23 \\
\hline 284 (a) & 35.8 & 1.2 & 6.4 & 4.4 & 0.19 & 212.7 & 4.3 & 45.0 & 7.40 & 335 & $1.3 \times 10^{-2}$ & 10.96 & 4.2 & 0.69 & 1.50 \\
\hline 284 (b) & 36.7 & 1.2 & 5.8 & 7.6 & 0.19 & 81.4 & 4.5 & 40.9 & 22.11 & 276 & $2.0 \times 10^{-3}$ & 8.33 & 5.8 & 62.70 & 1.13 \\
\hline 284 (c) & 16.4 & 1.2 & 6.6 & 6.6 & 0.19 & 91.4 & 4.4 & 35.4 & 22.63 & 237 & $6.5 \times 10^{-3}$ & 9.49 & 5.4 & 10.36 & 1.04 \\
\hline 284 (d) & 35.7 & 1.2 & 7.2 & 4.6 & 0.22 & 89.9 & 4.3 & 38.5 & 6.49 & 202 & $3.7 \times 10^{-3}$ & 11.37 & 5.3 & 0.67 & 1.13 \\
\hline $284(\mathrm{e})$ & 35.8 & 1.2 & 5.6 & 8.2 & 0.19 & 132.6 & 4.3 & 47.3 & 5.78 & 7 & $1.7 \times 10^{-2}$ & 9.79 & 4.9 & 53.5 & 1.13 \\
\hline 300 (a) & 17.1 & 36.6 & 4.8 & 5.7 & 0.27 & 86.3 & 23.7 & 647.0 & 82.16 & 322 & $2.4 \times 10^{-3}$ & 9.82 & 7.9 & 10.13 & 1.29 \\
\hline 300 (b) & 17.1 & 36.6 & 5.7 & 4.1 & 0.23 & 91.3 & 23.7 & 722.3 & 81.5 & 394 & $2.4 \times 10^{-3}$ & 9.41 & 8.6 & 12.04 & 1.06 \\
\hline 300 (c) & 36.9 & 36.6 & 5.5 & 4.2 & 0.18 & 82.2 & 4.9 & 793.9 & 75.5 & 314 & $8.0 \times 10^{-4}$ & 7.6 & 13.5 & 0.76 & 1.48 \\
\hline
\end{tabular}

N.p. = Not predicted; other abbreviations given in the Experimental Section. 


\section{Conclusions}

In this study, two different AOPs were examined to degrade metoprolol: UV-irradiation and ozonation. Hydrogen peroxide was found to accelerate the photo-induced degradation whereas $\mathrm{pH}$ had no significant effect. For ozonation, a saturated ozone solution led to faster metoprolol elimination than an ozone flow. Yet, the ozone-flow reactor arrangement might be optimized for similar performance. Overall, photo-irradiation proved the more efficient AOP. Although UV-irradiation may be technically more demanding, the use in WWTPs might be re-considered due to its efficiency and minimization of by-products. Capital and management cost, environmental impact, and safety risk would need to be balanced. Using HPLC-HRMS and MS/MS, secondary products could be elucidated. Due to excitation, hydroxyl radical and ozone reaction, degradation, and transformation products characteristic for the AOP and reaction mechanism were recognized. The secondary products were submitted to prediction of ecotoxicity using OECD QSAR toolbox and VEGA. In general, degradation products were predicted with lower ecotoxicity than metoprolol. Despite overall agreement of the two software tools, differences were found for isomers and ozonation products. While being valuable preliminary evaluation tools, databases for QSAR ecotoxicity need to be greatly extended in the future. The workflow to identify and monitor transformation products during AOP treatment by HPLC-HRMS, MS/MS and to assess their ecotoxicity by prediction software is suitable for other beta-blockers and pharmaceuticals.

Author Contributions: Conceptualization, M.V. and M.J.; methodology, M.V., L.V., D.S. and I.B.; software, M.V.; validation, M.V., I.B. and M.J.; formal analysis, M.V.; investigation, M.V., L.V., D.S. and I.B.; resources, K.H.-J.; data curation, M.V. writing-original draft preparation, M.V.; writingreview and editing, M.J., K.H.-J. and M.V.; visualization, M.V.; supervision, K.H.-J. and M.J.; project administration, K.H.-J. and M.J.; funding acquisition, K.H.-J. All authors have read and agreed to the published version of the manuscript.

Funding: This research was partially supported by EFRE NRW, project Enz4Water, grant number EFRE-0801523.

Institutional Review Board Statement: Not applicable.

Informed Consent Statement: Not applicable.

Data Availability Statement: The data presented in this study are available on request from the corresponding author. The data are not publicly available due to restrictions by Sciebo. The link will be provided upon request.

Conflicts of Interest: The authors declare no conflict of interest.

\section{References}

1. aus der Beek, T.; Weber, F.-A.; Bergmann, A.; Grüttner, G.; Carius, A. Pharmaceuticals in the Environment: Global Occurrence and Potential Cooperative Action under the Strategic Approach to International Chemicals Management (SAICM); Texte; Umweltbundesamt: Dessau, Germany, 2016; Volume 67.

2. Eike, D.; Marcus, R.; Dirk, J. The Database "Pharmaceuticals in the Environment"-Update and New Analysis; Texte; Umweltbundesamt: Dessau, Germany, 2019; Volume 67.

3. Santos, L.H.M.L.; Araújo, A.N.; Fachini, A.; Pena, A.; Delerue-Matos, C.; Montenegro, M.C.B.S.M. Ecotoxicological aspects related to the presence of pharmaceuticals in the aquatic environment. J. Hazard. Mater. 2010, 175, 45-95. [CrossRef]

4. Maszkowska, J.; Stolte, S.; Kumirska, J.; Łukaszewicz, P.; Mioduszewska, K.; Puckowski, A.; Caban, M.; Wagil, M.; Stepnowski, P.; Białk-Bielińska, A. Beta-blockers in the environment: Part II. Ecotoxicity study. Sci. Total Environ. 2014, 493, 1122-1126. [CrossRef]

5. Fick, J.; Söderström, H.; Lindberg, R.H.; Phan, C.; Tysklind, M.; Larsson, D.G.J. Pharmaceuticals and Personal Care Products in the Environment Contamination of Surface, Ground, and Drinking Water from Pharmaceutical Production. Environ. Toxicol. Chem. 2009, 28, 2522-2527. [CrossRef] [PubMed]

6. Maszkowska, J.; Stolte, S.; Kumirska, J.; Łukaszewicz, P.; Mioduszewska, K.; Puckowski, A.; Caban, M.; Wagil, M.; Stepnowski, P.; Białk-Bielińska, A. Beta-blockers in the environment: Part I. Mobility and hydrolysis study. Sci. Total Environ. 2014, 493, 1112-1121. [CrossRef] [PubMed] 
7. Voigt, M.; Wirtz, A.; Hoffmann-Jacobsen, K.; Jaeger, M. Prior art for the development of a fourth purification stage in wastewater treatment plant for the elimination of anthropogenic micropollutants-a short-review. AIMS Environ. Sci. 2020, 7, 69-98. [CrossRef]

8. Yang, Y.; Ok, Y.S.; Kim, K.H.; Kwon, E.E.; Tsang, Y.F. Occurrences and removal of pharmaceuticals and personal care products (PPCPs) in drinking water and water/sewage treatment plants: A review. Sci. Total Environ. 2017, 596-597, 303-320. [CrossRef] [PubMed]

9. Deng, Y.; Zhao, R. Advanced Oxidation Processes (AOPs) in Wastewater Treatment. Curr. Pollut. Rep. 2015, 1, 167-176. [CrossRef]

10. Parsons, S. Advanced Oxidation Processes for Water and Wastewater Treatment; IWA Publishing: London, UK, 2004.

11. Oppenländer, T. Photochemical Purification of Water and Air: Advanced Oxidation Processes (AOPs): Principles, Reaction Mechanisms, Reactor Concepts (Chemistry); WILEY-VCH Verlag: Weinheim, Germany, 2003; ISBN 3-527-30463-7.

12. Collivignarelli, M.C.; Abbà, A.; Miino, M.C.; Caccamo, F.M.; Torretta, V.; Rada, E.C.; Sorlini, S. Disinfection of wastewater by uv-based treatment for reuse in a circular economy perspective. Where are we at? Int. J. Environ. Res. Public Health 2021, 18, 77. [CrossRef]

13. Fatta-Kassinos, D.; Vasquez, M.I.; Kümmerer, K. Transformation products of pharmaceuticals in surface waters and wastewater formed during photolysis and advanced oxidation processes-degradation, elucidation of byproducts and assessment of their biological potency. Chemosphere 2011, 85, 693-709. [CrossRef]

14. Vasconcelos, T.G.; Henriques, D.M.; König, A.; Martins, A.F.; Kümmerer, K. Photo-degradation of the antimicrobial ciprofloxacin at high $\mathrm{pH}$ : Identification and biodegradability assessment of the primary by-products. Chemosphere 2009, 76, 487-493. [CrossRef]

15. Fick, J.; Andersson, P.L.; Johansson, M. Selection of Antibiotics: A Chemometric Approach Method. In Proceedings of the 4th International Conference Pharmaceuticals and Endocrine Disrupting Chemicals in Water, Minneapolis, MN, USA, 13-15 October 2004; pp. 143-150.

16. Wold, S.S.M.; Eriksson, L.; Sjöström, M.; Eriksson, L. PLS-regression: A basic tool of chemometrics. Chemom. Intell. Lab. Syst. 2001, 58, 109-130. [CrossRef]

17. Veith, G.D.; Mekenyan, O.G. A QSAR Approach for Estimating the Aquatic Toxicity of Soft Electrophiles [QSAR for Soft Electrophiles]. Quant. Struct. Relatsh. 1993, 12, 349-356. [CrossRef]

18. Pavan, M.; Worth, A.; Netzeva, T. Comparative Assessment of QSAR Models for Aquatic Toxicity; European Communities: Ispra, Italy, 2005.

19. Benfenati, E. E Book Theory, Guidance and Applications on QSAR and REACH; Orchestra: Milan, Italy, 2012; ISBN 9788890240546.

20. Dimitrov, S.D.; Diderich, R.; Sobanski, T.; Pavlov, T.S.; Chankov, G.V.; Chapkanov, A.S.; Karakolev, Y.H.; Temelkov, S.G.; Vasilev, R.A.; Gerova, K.D.; et al. QSAR Toolbox-workflow and major functionalities. SAR QSAR Environ. Res. 2016, 27, 203-219. [CrossRef]

21. Kuhn, H.; Braslavsky, S.E.; Schmidt, R. Chemical Actinometry. (IUPAC technical report). Pure Appl. Chem. 2004, 76, 2105-2146. [CrossRef]

22. Hatchard, C.G.; Parker, C. A New Sensitive Chemical Actinometer. II. Potassium Ferrioxalate as a Standard Chemical Actinometer. Proc. R. Soc. A Math. Phys. Eng. Sci. 1956, 235, 518-536. [CrossRef]

23. Kochany, J.; Bolton, J. of aqueous organic pollutants. 1. EPR spin-trapping technique for the determination of hydroxyl radical rate constants in the photooxidation of chlorophenols following. J. Phys. Chem. 1991, 95, 5116-5120. [CrossRef]

24. Sun, L.; Bolton, J.R. Determination of the Quantum Yield for the Photochemical Generation of Hydroxyl Radicals in TiO 2 Suspensions. J. Phys. Chem. 1996, 100, 4127-4134. [CrossRef]

25. Voigt, M.; Hentschel, B.; Theiss, N.; Savelsberg, C.; Bartels, B.; Nickisch-Hartfiel, A.; Jaeger, M. Lomefloxacin-Occurrence in the German River Erft, Its Photo-Induced Elimination, and Assessment of Ecotoxicity. Clean Technol. 2020, 2, 74-90. [CrossRef]

26. Voigt, M.; Jaeger, M. Structure and QSAR analysis of photoinduced transformation products of neonicotinoids from EU watchlist for ecotoxicological assessment. Sci. Total Environ. 2021, 751, 141634. [CrossRef]

27. Voigt, M.; Bartels, I.; Nickisch-Hartfiel, A.; Jaeger, M. Determination of minimum inhibitory concentration and half maximal inhibitory concentration of antibiotics and their degradation products to assess the eco-toxicological potential. Toxicol. Environ. Chem. 2019, 101, 315-338. [CrossRef]

28. Voigt, M.; Savelsberg, C.; Jaeger, M. Identification of Pharmaceuticals in The Aquatic Environment Using HPLC-ESI-Q-TOF-MS and Elimination of Erythromycin Through Photo-Induced Degradation. J. Vis. Exp. 2018. [CrossRef] [PubMed]

29. Voigt, M.; Bartels, I.; Nickisch-Hartfiel, A.; Jaeger, M. Elimination of macrolides in water bodies using photochemical oxidation. AIMS Environ. Sci. 2018, 5, 372-388. [CrossRef]

30. Abramović, B.; Kler, S.; Šojić, D.; Laušević, M.; Radović, T.; Vione, D. Photocatalytic degradation of metoprolol tartrate in suspensions of two $\mathrm{TiO}_{2}$-based photocatalysts with different surface area. Identification of intermediates and proposal of degradation pathways. J. Hazard. Mater. 2011, 198, 123-132. [CrossRef] [PubMed]

31. Cavalcante, R.P.; Dantas, R.F.; Bayarri, B.; González, O.; Giménez, J.; Esplugas, S.; Machulek, A. Photocatalytic mechanism of metoprolol oxidation by photocatalysts $\mathrm{TiO}_{2}$ and $\mathrm{TiO}_{2}$ doped with $5 \% \mathrm{~B}$ : Primary active species and intermediates. Appl. Catal. B Environ. 2016, 194, 111-122. [CrossRef]

32. Gao, Y.-Q.; Zhang, J.; Li, C.; Tian, F.-X.; Gao, N.-Y. Comparative evaluation of metoprolol degradation by UV/chlorine and $\mathrm{UV} / \mathrm{H}_{2} \mathrm{O}_{2}$ processes. Chemosphere 2020, 243, 125325. [CrossRef] 
33. Filipe, O.M.S.; Mota, N.; Santos, S.A.O.; Domingues, M.R.M.; Silvestre, A.J.D.; Neves, M.G.P.M.S.; Simões, M.M.Q.; Santos, E.B.H. Identification and characterization of photodegradation products of metoprolol in the presence of natural fulvic acid by HPLC-UV-MSn. J. Hazard. Mater. 2017, 323, 250-263. [CrossRef]

34. Neves, C.M.B.; Filipe, O.M.S.; Mota, N.; Santos, S.A.O.; Silvestre, A.J.D.; Santos, E.B.H.; Neves, M.G.P.M.S.; Simões, M.M.Q. Photodegradation of metoprolol using a porphyrin as photosensitizer under homogeneous and heterogeneous conditions. $J$. Hazard. Mater. 2019, 370, 13-23. [CrossRef]

35. Píšt'ková, V.; Tasbihi, M.; Vávrová, M.; Štangar, U.L. Photocatalytic degradation of $\beta$-blockers by using immobilized titania/silica on glass slides. J. Photochem. Photobiol. A Chem. 2015, 305, 19-28. [CrossRef]

36. Romero, V.; González, O.; Bayarri, B.; Marco, P.; Giménez, J.; Esplugas, S. Performance of different advanced oxidation technologies for the abatement of the beta-blocker metoprolol. Catal. Today 2015, 240, 86-92. [CrossRef]

37. Romero, V.; González, O.; Bayarri, B.; Marco, P.; Giménez, J.; Esplugas, S. Degradation of Metoprolol by photo-Fenton: Comparison of different photoreactors performance. Chem. Eng. J. 2016, 283, 639-648. [CrossRef]

38. Šojić, D.; Despotović, V.; Orčić, D.; Szabó, E.; Arany, E.; Armaković, S.; Illés, E.; Gajda-Schrantz, K.; Dombi, A.; Alapi, T.; et al Degradation of thiamethoxam and metoprolol by $\mathrm{UV}, \mathrm{O}_{3}$ and $\mathrm{UV} / \mathrm{O}_{3}$ hybrid processes: Kinetics, degradation intermediates and toxicity. J. Hydrol. 2012, 472-473, 314-327. [CrossRef]

39. Yu, Y.; Liu, Y.; Wu, X.; Weng, Z.; Hou, Y.; Wu, L. Enhanced visible light photocatalytic degradation of metoprolol by $\mathrm{Ag}^{-\mathrm{Bi}_{2} \mathrm{WO}_{6}-}$ graphene composite. Sep. Purif. Technol. 2015, 142, 1-7. [CrossRef]

40. Jaén-Gil, A.; Buttiglieri, G.; Benito, A.; Mir-Tutusaus, J.A.; Gonzalez-Olmos, R.; Caminal, G.; Barceló, D.; Sarrà, M.; RodriguezMozaz, S. Combining biological processes with UV/H2O2 for metoprolol and metoprolol acid removal in hospital wastewater. Chem. Eng. J. 2021, 404, 126482. [CrossRef]

41. Armaković, S.J.; Armaković, S.; Finčur, N.L.; Šibul, F.; Vione, D.; Šetrajčić, J.P.; Abramović, B.F. Influence of electron acceptors on the kinetics of metoprolol photocatalytic degradation in TiO2 suspension. A combined experimental and theoretical study. RSC Adv. 2015, 5, 54589-54604. [CrossRef]

42. Borkar, R.M.; Raju, B.; Srinivas, R.; Patel, P.; Shetty, S.K. Identification and characterization of stressed degradation products of metoprolol using LC/Q-TOF-ESI-MS/MS and MSn experiments. Biomed. Chromatogr. 2012, 26, 720-736. [CrossRef] [PubMed]

43. Romero, V.; De La Cruz, N.; Dantas, R.F.; Marco, P.; Giménez, J.; Esplugas, S. Photocatalytic treatment of metoprolol and propranolol. Catal. Today 2011, 161, 115-120. [CrossRef]

44. Gao, Y.Q.; Zhang, J.; Zhou, J.Q.; Li, C.; Gao, N.Y.; Yin, D.Q. Persulfate activation by nano zero-valent iron for the degradation of metoprolol in water: Influencing factors, degradation pathways and toxicity analysis. RSC Adv. 2020, 10, 20991-20999. [CrossRef]

45. Faber, H.; Lutze, H.; Lareo, P.L.; Frensemeier, L.; Vogel, M.; Schmidt, T.C.; Karst, U. Liquid chromatography/mass spectrometry to study oxidative degradation of environmentally relevant pharmaceuticals by electrochemistry and ozonation. J. Chromatogr. A 2014, 1343, 152-159. [CrossRef]

46. Radjenovic, J.; Escher, B.I.; Rabaey, K. Electrochemical degradation of the $\beta$-blocker metoprolol by $\mathrm{Ti} / \mathrm{Ru} 0.7 \mathrm{Ir} 0.3 \mathrm{O}_{2}$ and Ti/SnO ${ }_{2}-$ Sb electrodes. Water Res. 2011, 45, 3205-3214. [CrossRef]

47. Benner, J.; Ternes, T.A. Ozonation of metoprolol: Elucidation of oxidation pathways and major oxidation products. Environ. Sci. Technol. 2009, 43, 5472-5480. [CrossRef] [PubMed]

48. Tay, K.S.; Rahman, N.A.; Abas, M.R.B. Ozonation of metoprolol in aqueous solution: Ozonation by-products and mechanisms of degradation. Environ. Sci. Pollut. Res. 2013, 20, 3115-3121. [CrossRef] [PubMed]

49. Wilde, M.L.; Montipó, S.; Martins, A.F. Degradation of $\beta$-blockers in hospital wastewater by means of ozonation and $\mathrm{Fe}^{2+}$ /ozonation. Water Res. 2014, 48, 280-295. [CrossRef] [PubMed]

50. Heger, S.; Brendt, J.; Hollert, H.; Roß-Nickoll, M.; Du, M. Green toxicological investigation for biofuel candidates. Sci. Total Environ. 2021, 764, 142902. [CrossRef] [PubMed] 